\title{
DO INSTITUTO DA DELAÇÃO PREMIADA: CONCEITO, ABORDAGEM COMPARATIVA ALIENÍGENA, EVOLUÇÃO LEGISLATIVA NO BRASIL E POSICIONAMENTOS DOUTRINÁRIOS.
}

\author{
Raphael Douglas Vieira ${ }^{1}$ \\ Juan Pablo Morillas ${ }^{2}$
}

RESUMO: O presente trabalho, desenvolvido através de uma pesquisa bibliográfica, visa discorrer sobre o Instituto da Delação Premiada, seus aspectos históricos bem como sua evolução legislativa no Brasil, seus prós e contras, em uma abordagem doutrinária, na busca da compreensão de sua aplicação no Direito Penal Brasileiro, frente às constantes transformações vividas pela sociedade brasileira.

Palavras-chave: Delação; Premiada; Direito; Penal; Sociedade; História

\section{PLEA BERGAIN INSTITUTE: CONCEPT, ALIENEAL COMPARATIVE APPROACH, LEGISLATIVE EVOLUTION IN BRAZIL AND DOCTRINAL POSITIONING}

\begin{abstract}
The present work, developed through a bibliographical research, aims at discussing about "plea bargain" institute, as well as its historical aspects, legislative evolution in Brazil, pros and cons, within a doctrinal approach, in order to reach na understanding of its application in the Brazilian Criminal Law in the face of the constant changes experienced by brazilian society.
\end{abstract}

Key words: Plea; bargain; Law; Criminal; Society; History.

\footnotetext{
${ }^{1}$ Mestre em Segurança Pública, Cidadania e Direitos Humanos pela Universidade do Estado do Amazonas, Professor, Advogado, Consultor e Pesquisador na Área Criminal e Eleitoral. http://raphaeldouglas3.wixsite.com/advogado Email: raphaeldouglas@hotmail.com

${ }^{2}$ Major da Polícia Militar do Estado do Amazonas, Diretor do Centro Integrado de Comando e Controle- Secretaria Executiva Adjunta de Gestão Integrada da Secretaria de Segurança Pública do Estado do Amazonas- SEAGI/SSPAM e Mestrando em Segurança Pública, Cidadania e Direitos Humanos pela Universidade do Estado do Amazonas. Email: juanmorrilas@hotmail.com
} 


\section{INTRODUÇÃO}

Ultimamente, nos meios de comunicações no brasil só se têm falado em escândalos de corrupção, de esquemas gigantescos para desviar dinheiro público e investigações envolvendo tais crimes, como a operação "lava jato”, e vários processos em andamentos no poder judiciário envolvendo tais escândalos. Deve-se destacar que entre essas notícias, vem tomando grande destaque as colaborações que certos participantes vêm prestando a investigação, visando facilitar a solução de tais crimes cometidos, conhecida como "delação premiada”.

A operação "lava jato", permitiu que as delações evoluíssem a um patamar de importância jamais visto no brasil. Segundo o juiz federal sergio moro, responsável pelos processos decorrentes da operação "lava jato”, as colaborações premiadas são a melhor forma de solucionar crimes financeiros e empresariais.

Grande parte da classe dos operadores do direito veem a delação importante no meio jurídico, em vista do comportamento transgressor ou delituoso praticados com bastante frequência em áreas de grande relevância, que atentem contra a ordem pública, onde os mais comuns são contra a ordem financeira, econômica, ou crimes com potencial ofensivo maior, tráfico de drogas, etc. Da mesma forma, outra razão para utilizar de um mecanismo pouco convencional no combate a esses crimes, é que se alcança a efetividade do poder punitivo do estado, quando todos os envolvidos no delito são indicados e responsabilizados.

A delação premiada é frequentemente utilizada naqueles crimes com concurso de agentes, onde qualquer dos suspeitos se mostra disposto a colaborar com a revelação de todo o conjunto criminoso, inclusive de objetos, frutos do crime, bem como de pessoas que se encontrassem envolvidas com o fato criminoso investigado.

O instituto da delação premiada existe em nosso ordenamento jurídico desde época do império português, ela foi introduzida pela primeira vez pelas ordenações filipinas, promulgadas no início do século xvii, quando o brasil ainda se encontrava como colônia de portugal.

O tal mecanismo com o tempo veio tomando força em nosso ordenamento jurídico, vindo a ser previsto em diversas normas esparsas, como na: lei dos crimes hediondos - lei 8.072/90, na lei de proteção de vítimas e testemunhas - lei 9.807/99, na lei de drogas - lei 11.343/06, na lei das organizações criminosas - lei 12.850/13, onde a medida se tornou mais esclarecida e regulamentada, e ainda há previsão da delação no código penal, visto no $\S 4^{\circ}$ do art. 159. 
O instituto jurídico objeto desse trabalho, a delação premiada, é considerada pelos operadores do direito como uma medida de política criminal, adotada pelo ministério público, baseando-se na colaboração de um acusado, que indica a participação de mais pessoas na prática do mesmo crime, para que a polícia obtenha maior sucesso em suas investigações. A justiça com utilização da delação premiada no processo irá analisar o caso concreto, e ao chegar na fase de proferir sentença ao caso, concederá ao acusado que colaborou com a investigação, a diminuição de sua pena ou perdão judicial.

Assim, diante da relevância do tema referente ao instituto da "delação premiada" no brasil, e seus efeitos práticos, foi formulada a seguinte questão: “pode-se afirmar que o instituto da “delação premiada”, dentro dos parâmetros práticos e jurídicos, contribui positivamente para a aplicação da lei penal e para a diminuição da sensação de impunidade no brasil?”

O interesse em realizar este trabalho surge da associação entre o atual quadro em que se encontra a segurança pública no brasil, que há tempos vem se deteriorando a níveis inaceitáveis, conjugando violência, astúcia e sofisticação, bem como a importância adquirida pelo instituto da delação premiada no ordenamento jurídico pátrio nos últimos tempos. Em razão disso buscou-se realizar um estudo e análise que nos permitisse produzir conhecimentos pertinentes a uma maior compreensão do referido instituto frente às constantes transformações vividas pela sociedade brasileira.

Conforme veremos adiante, o presente artigo visa discorrer sobre o instituto da delação premiada, fazendo uma abordagem comparativa deste instituto no brasil e em outros países, sua conceituação, evolução histórica, bem como os seus aspectos legais e doutrinários na busca da compreensão de sua aplicação no direito penal brasileiro.

Para o presente estudo utilizou-se como metodologia a pesquisa bibliográfica. Para realizar a pesquisa foi necessário levantar bibliografias identificando as informações-chave e organizando dados para, finalmente, redigir o texto.

\section{CONCEITO ETIMOLÓGICO DO INSTITUTO DA “DELAÇÃO PREMIADA” E AS DENOMINAÇÕES ADOTADAS POR OUTROS PAÍSES E PELO BRASIL.}

Segundo o Dicionário Aurélio, o significado dos verbos que dão origem ao Instituto da “Delação Premiada” são: 
de.la.tar v.t.d. 1. Denunciar, revelar (crime ou delito). 2. V. denunciar (1 e 2). T.d.i 3. Denunciar como culpado. P. 4. Denunciar-se como culpado.

..

pre.mi.ar v.t.d 1. Conceder prêmio ou galardão a. Recompensar, remunerar. §premi.a.ção s.f.; pre.mi.a.do adjetivo (FERREIRA, 2008, p. 280 e p. 650)

Do conceito acima transcrito, pode-se inferir que a palavra “delação” tem sentido de denúncia, revelação e até mesmo de confissão (denunciar-se como culpado).

A adoção do termo "premiada" é discutida doutrinariamente, posto que levaria a cabo de interpretação como reconhecimento pelo Estado de seu fracasso para apurar, processar e julgar determinados crimes, conforme disciplina MOSSIM \& MOSSIM (2016, p. 29):

Em circunstâncias desse matiz, procurando combater essa fragilidade, a própria incompetência do Estado em reprimir as práticas delitivas, buscou-se uma alternativa, por sinal pouco recomendada, uma vez que obriga o aplicador do Direito a conferir recompensa ao criminoso que denuncia seu comparsa, quer diminuindo sua pena na eventualidade de ser condenado, quer, de maneira extrema, conferindo-lhe perdão judicial, que se constitui causa extintiva de punibilidade (art. 107, inciso IX, CP). O que se conclui é que o Estado se aliou ao delinquente para ambos lutarem em oposição à criminalidade.

Em razão da imparcialidade do juiz, o sistema de justiça criminal do Brasil veda por parte do magistrado sua atuação na persecução criminal, pois impera o sistema acusatório, em que existe o actum trium personarum (separação da função de acusar, defender e julgar), diferentemente do que ocorre no sistema inquisitório.

Vale dizer, ao Ministério Público cabe a persecução penal e à polícia judiciária cabe investigar, colhendo elementos de prova de autoria e materialidade que servirão de subsídios de convencimento à propositura da ação penal, ou seja, ao dominus litis do processo penal (Parquet). Nessa inteligência, caminha MOSSIM (2016, p. 49), vejamos:

A mencionada delação deve ser feita à “autoridade” cuja expressão deve ser entendida
em sentido estrito, compreendendo unicamente a "autoridade policial”, porquanto é a
ela que cumpre desmantelar o grupo criminoso. Nada impede, outrossim, que a
delação seja dada ao Ministério Público, pois sendo órgão da percussão criminal, pode
cooperar com a autoridade policial. Logo, ambos conjuntamente podem concorrer
para que se verifique o resultado buscado pelo legislador com a ajuda do "dedo-duro".
Exclui-se do âmbito da palavra "autoridade” o juiz, quer se cuide de estadual, quer se
trate de federal, posto que sua atividade deve ser precipuamente de cunho processual
e jamais de natureza persecutória, ressalvadas as hipóteses em que o legislador previu
a “confissão espontânea” em nível processo penal, a exemplo do que ocorre com o
crime contra o Sistema Financeiro (Lei n. 7.492/1986); contra a Ordem Tributária (Lei
n. 8.137/1990). Em outros países a delação premiada é termo de ajuste entre o Ministério Público e o acusado/réu, podendo o Parquet, inclusive, dispor da ação criminal, ou não realizar a estrita 
subsunção do fato à norma penal, no modelo ponteano conhecido no Brasil, apresentando denúncia “mais branda” ao Judiciário.

De acordo com a definição cunhada por Walter Bittar, a delação premiada consiste na concessão de um prêmio ao imputado, que varia de redução da pena até o perdão judicial, pela confissão e pela sua colaboração com os procedimentos persecutórios, realizados de forma espontânea (BITTAR, Walter Barbosa. Delação premiada: direito estrangeiro, doutrina e jurisprudência. Rio de Janeiro: Lumen Juris, 2011 apud BRITO, Michelle Barbosa de. Delação Premiada e decisão penal: da eficiência à integridade. Belo Horizonte: D’Plácido, 2016)

Pela leitura atenta do conceito transcrito, temos que a confissão é um pressuposto para a delação, na medida em que se não tivermos a confissão do crime, existirá somente a delação em sua forma e simples. Trazemos as lições didáticas de MOSSIM (2016, p. 40) sobre o tema:

\begin{abstract}
Em um primeiro momento, a delação foi na linguagem forense mais propriamente para designar a denúncia de um delito, praticado por pessoa, sem que o denunciante (delator) se mostre parte interessada diretamente na sua repressão, feita perante autoridade judiciária ou policial a quem compete a iniciativa de promover a verificação da denúncia e punição do criminoso.

Toma-se, a delação no sentido pejorativo, visto que, em regra, a consideram produto de vingança ou ódio ou qualquer outra paixão, quando além do desejo fazer mal, não ocorre na intenção de se conseguirem proventos materiais legais ou outros benefícios. Ao lado dessa modalidade de delação, surgiu uma outra seguida do adjetivo "premiada" que é implicativa de recompensa. Disso resulta que essa modalidade de delação é utilizada por pessoa envolvida no delito e que procura obter o benefício da redução ou mesmo isenção das penas respectivas, na dependência de norma a respeito. De uma maneira geral, o delinquente que entrega seu comparsa em determinadas situações delituosas tem como prêmio a redução de sua reprimenda legal ou o perdão judicial. (MOSSIM, Antônio Heráclito e MOSSIM, Júlio César O.G. Delação premiada: aspectos jurídicos. São Paulo: J.H. Mizuno, 2016, p. 40)
\end{abstract}

Para BRITO (2016, p. 54) “a delação não se confunde com a confissão. Confessar significa admitir a autoria ou a participação em crime. É o ato pelo qual o imputado “opta” por declarar-se autor ou partícipe do delito, assumindo a responsabilidade pelo ato”.

O instituto de denúncia de comparsas que traz benefícios ao agente de delator, é a delação premiada, segundo a legislação vigente. Entretanto, parte da doutrina fala em colaboração premiada. Seguimos a linha da doutrina que não vê diferença entre os dois, pois, para efeitos práticos levam à mesma consequência jurídica, cingindo-se a discussão apenas no tocante à questão terminológica.

Valemo-nos dos estudos de Ana Lúcia Stumpf González (2010, p. 10) para trazer à tona as várias denominações adotadas por outros países: 
a expressão “arrepentito” é utilizada pela doutrina espanhola para denominar o acusado que se vale do instituto da delação premiada. Na Itália, a expressão utilizada na lei é "colaboratori della giustizia”, contudo, os delatores ficaram conhecidos como “pentiti”. Nos Estados Unidos da América emprega-se a denominação “state’s witness”, sendo que o instituto da negociação entre órgão acusatório e acusado, que resulta na qualificação deste como "state’s witness", recebe a denominação de "plea bargaining”. A doutrina brasileira também utiliza as denominações "chamamento de corréu”, “arrependimento processual” e “cooperação pós delitiva de coautor”.

\title{
2. O TRATAMENTO DA DELAÇÃO PREMIADA EM OUTROS PAÍSES.
}

\subsection{DIREITO ITALIANO.}

A Itália, na perspectiva histórica, foi o primeiro país, no século $\mathrm{XX}$, a se destacar com a aplicação do instituto da delação premiada. Segundo MOSSIM \& MOSSIM (2016, p.33):

\begin{abstract}
Do ponto de vista histórico, no que diz respeito ao surgimento da delação premiada no direito estrangeiro, o instituto se notabiliza na Itália, a partir de 1970, em que se procurou criar mecanismo para combater o terrorismo e a extorsão mediante sequestro, subversão da ordem democrática e sequestro com finalidade terrorista, propiciando uma apenação menos rigorosa todos aqueles que cooperavam no combate a esse tipo de delito, tidos como "Colaboradores da Justiça", desde que cumpridos os requisitos legais. [...]

Nessa época a imprensa italiana criou o chamado "pentinismo" com a precípua finalidade de indicar a figura penal que se encontrava encartada no art. $3^{\circ}$ da Lei $n^{\circ}$ 304/82. Era assim o apelido do agente que, na vigência do Código Penal, confessa sua própria responsabilidade, em termos de prática delitiva, assim como provia às autoridades de notícias úteis objetivando a reconstituição de fatos delituosos aliados notadamente ao terrorismo e a individualização das pessoas que envolveram na respectiva prática delituosa.
\end{abstract}

Na legislação Italiana houve a tipificação da associação de pessoas à Máfia, a fim de mitigar a criminalidade organizada, bem como o incremento da Delação Premiada, que objetivava a quebra da lei do silêncio/código de honra que impera dentro de cada organização mafiosa, a Omertà.

A delação premiada mais famosa da história italiana foi a de Tommaso Buscetta, a primeira testemunha importante do Estado, que ajudou o Juiz Giovanni Falcone a compreender o funcionamento interno da Cosa Nostra e ainda descreveu a Comissão da Máfia Siciliana como a “Cupola”.

Graças a mencionada delação, Falcone presidiu o maior processo da história italiana, com 331 condenações, entre eles o alto escalão da Máfia, naquela que ficou conhecida como “operação mãos limpas”. 
Utilizando a didática de Sérgio Fernando Moro, juiz federal em Curitiba, citamos

ipsis litteris seus ensinamentos:

A denominada “operação mani pulite” (mãos limpas) constitui um momento
extraordinário na historia contemporânea do Judiciário. Iniciou-se em meados de
fevereiro de 1992, com a prisão de Mario Chiesa, que ocupava o cargo de diretor de
instituição filantrópica de Milão (Pio Alberto Trivulzio). Dois anos após, 2.993
mandados de prisão haviam sido expedidos; 6.059 pessoas estavam sob investigação,
incluindo 872 empresários, 1.978 administradores locais e 438 parlamentares, dos
quais quatro haviam sido primeiros-ministros. A ação judiciária revelou que a vida
política e administrativa de Milão, e da própria Itália, estava mergulhada na corrupção,
com o pagamento de propina para concessão de todo contrato público, o que levou à
utilização da expressão “Tangentopoli” ou "Bribesville” (o equivalente à “cidade da
propina') para designar a situação. A operação mani pulite ainda redesenhou o quadro
político na Itália. Partidos que haviam dominado a vida política italiana no pós-guerra,
como o Socialista (PSI) e o da Democracia Cristã (DC), foram levados ao colapso,
obtendo, na eleição de 1994, somente 2,2\% e 11,1\% dos votos, respectivamente.
Talvez não se encontre paralelo de ação judiciária com efeitos tão incisivos na vida
institucional de um país. Por certo, tem ela os seus críticos, especialmente após dez
anos. Dez suspeitos cometeram suicídio. Silvio Berlusconi, magnata da mídia e um
dos investigados, hoje ocupa o cargo de primeiro-ministro da Itália. (MORO, 2004, p.
56-62)

Certo é que, após a adoção da Delação Premiada, a Justiça italiana, conseguiu desmantelar a maior Máfia que assolava o país, a Cosa Nostra, notabilizando-se como uma eficiente “arma” legal a favor do Estado, no combate às organizações criminosas. Por isso, é conservada em seu Ordenamento Jurídico, no Código Penal vigente:

De um modo geral para efeito de cunho legislativo, o instituto abordado se encontra, na Itália, disciplinado pelo Código Penal, nos arts. 289bis (sequestro de pessoa com o fim de terrorismo ou subversão), inciso IV (II concorrente che, dissociando dagli altri, si adopera in modo che il soggetto passivo riacquisiti la libertà é punito com la reclusione da due a otto anni(...) e 630 (sequestro da pessoa com o fim de extorsão), inciso IV (al concorrente che, dissociando dagli altri, si adopera in modo che il soggetto passivo riacquisiti la libertà, senza che tale resultado sai consequenza dell prezo liberazionem si aplicano le pene preveste dall”articolo 605 (MOSSIM \& MOSSIM, 2016, p. 33)

A Legislação Italiana, no que tange ao Instituto da delação premiada, foi importada pelo Brasil quase em sua totalidade, tamanha sua importância no combate ao crime organizado.

\subsection{DIREITO ESPANHOL.}

A delação premiada surgiu da necessidade da Espanha combater, através de instrumentos eficazes, as ações de grupos separatistas, como Bascos, ETA e GRAPO (Grupos 
Antifascistas Primeiro de Outubro), na década de 1970, dado o contexto social naquele período (GONZALES, 2010, p. 19).

O Direito espanhol prevê o instituto da delação premiada em determinados crimes, como a organização criminosas e o tráfico de entorpecentes. O direito penal espanhol prevê que o agente delator haja de forma espontânea e voluntária, sem interferências externas, da justiça ou do cerceamento da liberdade.

A legislação espanhola adotou, para a validação da delação premiada, da deontologia do filósofo alemão Immanuel Kant, posto que, para aquela, a causa da ação tinha que se dar pelo dever, com o chamado imperativo categórico, não podendo haver, desse modo, um interesse egoísta, mas altruísta, em prol do bem comum.

O código penal espanhol prevê a redução de pena para o colaborador, não podendo controlar a finalidade da ação delatora por parte de quem a faz. Pode, no entanto, diminuir as pressões externas, do meio social, a fim de proporcionar ao participante da organização criminosa a sensibilização mais moral do que jurídica, com o intuito de cumprir dois desejos: o desmantelamento da organização e o incentivo a práticas morais mais saudáveis.

Segundo MOSSIM \& MOSSIM (2016, p. 34-35), o código penal espanhol utilizase da delação premiada no crime de tráfico de entorpecentes, senão vejamos:

Na legislação espanhola os artigos 376 e 579, n.3, contém previsão legal em torno da
delação premiada. Na forma do art. 376 a benesse legal cuidada incide sobre o crime
de cultivo de drogas tóxicas, estupefacientes ou substancias psicotrópicas, cuja
conduta vedada se encontra inserida no art. 368 do código penal espanhol.
Também se incluem no campo do instituto estudado o crime de organização criminosa
(art. 369); o uso de menores de 18 anos ou psiquicamente diminuídos (art. 370, § 1);
fabrico, transporte, distribuição, comércio de substância entorpecente (art. 371) e
também quando o crime for praticado por pessoas enumeradas no art. 372 do referido
código.
Para a hipótese sublinhada, os juízes ou os Tribunais podem impor pena inferior a um
ano, sempre que o sujeito tenha abandonado voluntariamente suas atividades delitivas
e tenha colaborado ativamente com as autoridades ou seus agentes, para impedir a
produção do delito, para obter provas decisivas para a identificação ou captura de
outros responsáveis, ou ainda, para impedir a atuação ou desenvolvimento de
organizações ou associações a que tenha pertencido ou com as quais tenha colaborado.

Em relação aos crimes cometidos por organizações criminosas, ainda na esteira de dos autores mencionados acima:

Consoante dispositivo contido no art. 579, n. 4, do código penal espanhol na mesma maneira que ocorreu na hipótese anteriormente mencionada, os juízes e tribunais poderão impor uma pena inferior a um ano, quando sujeito tenha abandonado voluntariamente suas atividades delitivas e se apresente às autoridades confessando os fatos em que tenha participado e ademais colabore ativamente com essas para impedir a produção do delito ou coopere eficazmente na obtenção de provas decisivas 
para a identificação ou captura de outros responsáveis ou para impedir a atuação ou o desenvolvimento de organizações ou grupos terroristas aos que tenha pertencido ou com os que haja colaborado. Os fatos puníveis abrangidos pelo supradito comando normativo são os chamados “delitos de terrorismo”, encartados nos arts. 572 e 578 do predito Códex. (MOSSIM \& MOSSIM, 2016, p. 34-35)

Em 2003, uma reforma no instituto da delação premiada realizado pela Lei Orgânica 15/2003, que passou a vigorar no ano de 2004, dispensou a confissão como elemento para aplicação da citada causa de diminuição de pena (GONZALES, 2010, p. 20-21).

Além disso, ainda que o réu esteja cumprindo pena, é possível que se tenha a delação premiada do mesmo e, por consequência, a obtenção de benefícios, tais como a concessão da liberdade provisória.

\subsection{DIREITO NORTE-AMERICANO (ESTADOS UNIDOS DA AMÉRICA).}

A delação premiada foi instituída no Ordenamento jurídico nos Estados Unidos através da Lei Ricco (Racketeer Influenced and Corrupt Organization Act), em 1970, pelo então Presidente da República Richard Nixon, visando combater as organizações criminosas que assolavam os EUA, de cunho mafioso.

É um instituto específico, que não deve ser confundido com o sistema da plea bargaining, que se consubstancia em uma negociação antes do processo realizado entre o órgão acusador (Ministério Público) e o acusado, sendo bastante utilizado tal política criminal, no Direito Penal americano.

Ao ser acusado de crime nos Estados Unidos há três opções: ou se declara inocente, sendo julgado pelo Tribunal do Júri; ou, mesmo se declarando inocente, renuncia ao direito de ser julgado pelo Tribunal Popular; ou, ainda, se declara culpado. Neste último, o declarante pode fazer um acordo com o Ministério Público para receber uma acusação menos grave, ou até mesmo não receber nenhuma acusação.

Atente-se, que para a questão que, nos Estados Unidos, o Parquet pode dispor da ação penal, quando realiza acordos, ou seja, tem a possibilidade de escolher se oferece ou não a denúncia. Essa disposição decorre do sistema da commom law.

Na delação premiada norte-americana não se permite a não aplicação de pena ao delator, mas tão somente uma diminuição de pena, caso a mesma preencha os requisitos legais. 


\section{EVOLUÇÃO LEGISLATIVA NO BRASIL.}

\subsection{ORDENAÇÕES FILIPINAS.}

A delação premiada no Brasil tem duas existências, em contextos sociais distintos. Temos as Ordenações Filipinas (1603-1830) e as atuais legislações sobre o instituto, iniciando com a Lei 8 072/1990 (crimes hediondos).

Antes da vigência do Código Criminal de 1850, três Ordenações oriundas de Portugal regraram as condutas criminosas, entre outras, dos habitantes do Brasil, a saber: as Ordenações Manuelinas, as Afonsinas e, por último as Filipinas. Ao conjunto formado por essas legislações oriundas de Portugal foi dado o nome de Ordenações do Reino.

Quando Pedro Álvares Cabral aportou no Brasil em 22 de abril de 1500, o reino português era regido pelas Ordenações Manuelinas, fato que estendeu aos colonos o mesmo regramento até 1514. Entretanto, como a maioria dos habitantes de “Terra de Vera Cruz” eram índios, e Portugal pouco se interessou pelo Brasil nos trintas primeiros anos, não existiam muitos portugueses por cá, fato que fez com que quase fosse inexistente à aplicação da Ordenações Manuelinas.

Depois de 1514 até 1603, o Brasil-Colônia foi regido pelas Ordenações Afonsinas, que, em virtude da alta complexidade e de sua vastidão, pouco se aplicaram ao Brasil na época. O que valia mesmo era a vontade autoritária dos colonos portugueses que viviam aqui, longe das vistas da justiça portuguesa, não sendo levado em consideração as regras de convivência social entre os primeiros habitantes da Colônia.

A partir de 1603, entram em vigor as Ordenações Filipinas, essas disciplinando as condutas criminosas até a sua revogação pelo Código Criminal de 1850. Foram mais de duas centenas de anos, disciplinando a vida social dos habitantes do Brasil, sendo o conjunto de regras mais longo da nossa história desde a chegada dos portugueses.

Quanto a essas últimas Ordenações, elas carregavam o nome do rei espanhol Filipe II (1580-1640), que promoveu a União Ibérica, vale dizer, que uniu os reinos de Portugal e Espanha em 1580, a fim de preservar os reinos católicos. Nesse momento histórico nascia a delação premiada, permitida nos crimes de Lesa Majestade.

Lesa Majestade quer dizer traição comettida contra a pessoa do Rey, ou seja, Real Stado, que he tão grave e abominável crime, e que os antigos Sabedores tanto estranharão, que o comparavão à lepra; porque assi como esta enfermidade enche todo o corpo, sem nunca mais se poder curar, e empece ainda aos descendentes de que a 
tem, e aos que com ele conversão, polo que he apartado da comunicação da gente; assi o erro da traição condena o que comette, e empece e infama os que de sua linha descendem, pos-toquem não tenhão culpa.

[...] Se algum tratasse a morte de seu Rey, ou da Rainha sua mulher, ou de alguns de seus filhos, ou filhas legítimas. Ou a isso desse ajuda, conselho e favor;

Se o que tiver Castelo, ou Fortaleza do Rey, ele, ou àquelle que da sua mão a tiver se levantar com ella, e não a entregar logo à pessoa do Rey, ou a quem para isso seu special mandado tiver, ou a perder por sua culpa;

Se em tempo de guerra algum se fosse para os inimigos do Rey, para fazer guerra aos lugares do seu Reinos;

Se alguém der conselho aos inimigos do Rey per canta, ou per qualquer outro aviso em seu desserviço, ou de seu Real Stado; [...] (PIERAGELI, 2016, p. 38)

Ainda se tem as condições de eventual perdão:

E quanto que fizer conselho e confederação contra o Rey, se logo sem algum spaço, e antes que por outrem seja descoberto, ele o descobrir, merece perdão;

E ainda por isso lhe deve ser feita mercê, segundo o caso merecer, se ele não foi o principal tratador desse conselho e confederação;

E ainda por isso lhe deve ser feita mercê, segundo o caso merecer, se ele não foi o principal tratador desse conselho e confederação.

E não o descobrindo logo, se o descobrir depois por spaço de tempo, antes que o Rey seja disso sabedor, nem feita obra por isso, ainda deve ser perdoado, sem haver outra mercê.

E em todo caso que descobrir o tal conselho, sendo já per outrem descoberto, ou posto em ordem para se descobrir, será havido por compromettedor do crime de Lesa Majestade, sem ser relevado da pena, que por isso merecer, pois o revoltou em tempo, que o Rey já sabia, ou estava de maneira para o não poder deixar de saber. (PIERAGELI, 2016, p. 100-101)

O perdão dado pela Coroa portuguesa era dado nos seguintes termos:

Qualquer pessoa, quer der à prisão cada hum dos culpados, e participantes em fazer moeda falsa, ou em cercear, ou per qualquer artificio mingoar, ou corromper a verdadeira ou em falsar nosso sinal, ou sello, ou da Rainha ou do Príncipe meu filho, ou em falsar sinal de algum Védor da nossa fazenda, Desembargador, ou de outro nosso Official Mór, ou de outros Oficiais de nossa Caza, em cousas, que foquem a seus Officios, ou em matar, ou ferir bêsta, ou empigarda, matar com peçonha, ou em dar, ainda que morte dela se não siga, em matar atraiçoadamente, quebrantar prisões cadêas de fora per força, per furto, de qualquer sorte e maneira que seja, pôr fogo acinte para queimar fazenda, ou pessoa, forçar mulher, fazer feitiços, testemunhar falso, em soltar presos por sua vontade, sendo Carcereiro, em entrar em Mosteiro de Freiras com propósitos desonesto, em fazer falsidade em seu Officio, sendo Tabellião, ou Scrivão; tanto que assi dêr à prisão dos ditos malfeitores, ou cada um deles, e lhes provar, ou forem provados cada um dos ditos malefícios, em que he culpado aquelle, que he preso, havemos por bem que, sendo igual na culpa, seja perdoado livremente, postoque não tenha perdão da parte. E que se não for participante no mesmo malefício, queremos que haja perdão par si (tendo perdão das partes) de qualquer malefício, que tenha, postoque grave seja, e isto não sendo maior daquele, em que he culpado oq eu assi deu à prisão. Porém, isto se entenderá, que o que der à prisão malfeitor, não seja perdão de mais pena, nem degredo, que de outro tanto, quando o malfeitor merecer. (MOSSIM \& MOSSIM, 2016, p. 39) 
O interessante de se notar é que a delação premiada pelo crime de Lesa Majestade tinha como condição ser a denúncia feita pelo delator anterior a qualquer conhecimento por parte da autoridade, nesse caso, o rei, sobre o crime. Sendo assim, se o crime já tivesse sido dado ao Reino, não tinha efeito nenhum a delação, posto que já estaria revelada por outras fontes. Estava vedado, nessa hipótese, o perdão.

Foi pensando nesse perdão e em quanto iria lucrar que Joaquim Silvério da Silva dos Reis (1756-1819) participou como delator premiado de uma desconstituição da Inconfidência Mineira no dia 15 de março de 1879, quatro meses, portanto, antes da Revolução Francesa.

É o que dizia os Autos da Devassa da Inconfidência Mineira (1789-1792), processo que foi iniciado a partir da delação de Joaquim Silvério dos Reis.

Os outros inconfidentes foram condenados ao degredo, enquanto o delator Silvério dos Reis teve suas dívidas perdoadas, recebeu uma recompensa em ouro e mais algumas honrarias, à época.

\subsection{LEI 8.072 DE 25 DE JULHO DE 1990 (CRIMES HEDIONDOS).}

Passada nossa grande e primeira experiência com a delação de Joaquim Silvério dos Reis, em 1789, que resultou ao delator recompensas de grande valia, temos que, já no Brasil-República, surge, após a Constituição Federal de 1988, a Lei de crimes hediondos no ano de 1990.

Em relação à delação premiada, apontamos que o art. $8^{\circ}$, caput, da Lei referida estabelece o quantum de pena aplicada à associação criminosa que praticar crimes hediondos e equiparados (tortura, tráfico de entorpecentes e terrorismo), bem como o parágrafo único do mesmo dispositivo diz aplicar causa de diminuição de pena ao integrante da associação criminosa que denunciar os comparsas. Vejamos o que diz a norma citada:

Art. $8^{\circ}$ Será de três a seis anos de reclusão a pena prevista no art. 288 do Código Penal, quando se tratar de crimes hediondos, prática da tortura, tráfico ilícito de entorpecentes e drogas afins ou terrorismo.

Parágrafo único. O participante e o associado que denunciar à autoridade o bando ou quadrilha, possibilitando seu desmantelamento, terá a pena reduzida de um a dois terços. (texto original de 1990) 
O crime hediondo ou assemelhado (tortura, tráfico de entorpecentes, terrorismo), em associação criminosa, permite benefícios análogos aos da delação premiada, com redução da pena de um a dois terços.

Entretanto, a figura da delação premiada propriamente dita só apareceu em 1996, com a Lei 9269, que incluiu o $\S 4^{\circ}$ ao art. 159 do Código Penal. Anotamo-nos, abaixo, na ordem respectiva de exposição:

Art. $1^{\circ}$ São considerados hediondos os seguintes crimes, todos tipificados no DecretoLei $n^{0}$ 2.848, de 7 de dezembro de 1940 - Código Penal, consumados ou tentados: (Redação dada pela Lei $n^{\circ} 8.930$, de 1994)

$[\ldots]$

IV - extorsão mediante sequestro e na forma qualificada (art. 159, caput, e $\S \S 1^{\circ}, 2^{\circ} \mathrm{e}$ 30); (Inciso incluído pela Lei n 8.930 , de 1994)

Art. 159 - Sequestrar pessoa com o fim de obter, para si ou para outrem, qualquer vantagem, como condição ou preço do resgate.

[...]

$\S 4^{\circ}$ - Se o crime é cometido em concurso, o concorrente que o denunciar à autoridade, facilitando a libertação do sequestrado, terá sua pena reduzida de um a dois terços. (Redação dada pela Lei n ${ }^{\circ}$ 9.269, de 1996)

Chama à atenção que, neste último caso, embora o crime de extorsão mediante sequestro seja hediondo, não precisa ele ser cometido em associação criminosa (três ou mais pessoas), bastando para tanto ser cometido em concurso de pessoas (basta 2 pessoas num concurso eventual, voluntário, ou crime monossubjetivo). Note ainda que a delação premiada está condicionada à eficácia da contribuição do agente, na facilitação da libertação do sequestrado.

Quanto à natureza jurídica da delação, não há dúvidas, ou sobressaltos, pois que é causa de diminuição da pena tanto no art. $8^{\circ}$, parágrafo único, como no art. $1^{\circ}$, inciso IV (todos da Lei 8 072/1990), o qual deu redação ao art. 159, caput e seus $\S \S 1^{\circ}, 2^{\circ}$ e $3^{\circ}$ do Código Penal.

Antes da vigência da Lei 9 269/1996, que trouxe o $§ 4^{\circ}$ do art. 159, registre-se que o crime de extorsão mediante sequestro, tinha, como condição para o uso da delação premiada, ser cometido em quadrilha ou bando (concurso necessário de mais de três pessoas). O que ocorreu foi a flexibilização dessa condição, podendo ser delator o agente em concurso eventual.

Sob o manto da emergência, a delação premiada foi tratada no contexto republicano-democrático brasileiro, sendo a Lei 8.072/1990 a primeira a positivar o tema.

\subsection{LEI 9.034 DE 03 DE MAIO DE 1995 (1ª LEI CONTRA O CRIME ORGANIZADO).}


Foi a primeira Lei que trouxe a expressão “crime organizado”, sem contudo estipular sua definição legal, o que acabou gerando inúmeros transtornos jurídicos, pois na aplicação da lei era utilizada a terminologia prevista na Convenção das Nações Unidas contra o Crime Organizado Transnacional, adotada em Nova York, em 15 de novembro de 2000, mas conhecida como Convenção de Palermo, definição legal esta que, dada sua amplitude, não era razoável, mormente ao combate dos crimes e organizações a que se pretendia.

A desejada precisão terminológica conceitual só veio a acontecer com a promulgação da Lei 12.694 de 24 de julho de 2012, vejamos:

Art. $2^{\circ}$ Para os efeitos desta Lei, considera-se organização criminosa a associação, de 3 (três) ou mais pessoas, estruturalmente ordenada e caracterizada pela divisão de tarefas, ainda que informalmente, com objetivo de obter, direta ou indiretamente, vantagem de qualquer natureza, mediante a prática de crimes cuja pena máxima seja igual ou superior a 4 (quatro) anos ou que sejam de caráter transnacional.

A partir da vigência desta lei a delação premiada (chamada de colaboração espontânea) era prevista em seu bojo, possuindo natureza jurídica de causa de diminuição de pena de um a dois terços, conforme dispunha seu o artigo $6^{\circ}$.

\subsection{LEI 9.080 DE 19 DE JULHO DE 1995.}

Essa Lei teve caráter específico de alteração da Leis 7.492 de 16 de junho de 1986 e 8.137 de 27 de dezembro de 1998, as quais, respectivamente, versavam sobre crimes contra o sistema nacional financeiro; e contra a ordem econômica, tributária e relações de consumo.

Teve a finalidade de acrescentar o $\S 2^{\circ}$ ao art. 25 da Lei 7.492/1986 e parágrafo único ao art. 16 da Lei 8.137/1990.

Art. $1^{\circ}$ Ao art. 25 da Lei no 7.492, de 16 de junho de 1986, é acrescentado o seguinte parágrafo:

"Art. 25.

$\S 2^{\circ}$ Nos crimes previstos nesta Lei, cometidos em quadrilha ou co-autoria, o co-autor ou partícipe que através de confissão espontânea revelar à autoridade policial ou judicial toda a trama delituosa terá a sua pena reduzida de um a dois terços."

Art. $2^{\circ}$ Ao art. 16 da Lei $\mathrm{n}^{\circ}$ 8.137, de 27 de dezembro de 1990, é acrescentado o seguinte parágrafo único:

"Art. 16.

Parágrafo único. Nos crimes previstos nesta Lei, cometidos em quadrilha ou coautoria, o co-autor ou partícipe que através de confissão espontânea revelar à autoridade policial ou judicial toda a trama delituosa terá a sua pena reduzida de um a dois terços." 
Esta lei também utilizava a expressão colaboração espontânea para se referir ao instituto da delação premiada, que na esteira de outras leis precedentes possuía natureza jurídica de causa de diminuição de pena. Além do apontado, a referida lei traz à baila o termo trama delituosa, conceito jurídico indeterminado e impreciso.

\title{
3.5. LEI 9613 DE 03 DE MARÇO DE 1998.
}

Essa lei trata do crime de lavagem de dinheiro. Entretanto, a lei lhe empregou um sentido mais amplo e técnico, preferindo chamar de crimes de "lavagem" ou ocultação de bens, direitos e valores.

A delação premiada para essa espécie de crime surgiu na redação original desta lei, mas foi alterada por meio da Lei 12.683 de 2012, que acrescentou a expressão “a qualquer tempo”. Vamos nos valer da leitura da norma referida:

\begin{abstract}
Art. $1^{\circ}$ Ocultar ou dissimular a natureza, origem, localização, disposição, movimentação ou propriedade de bens, direitos ou valores provenientes, direta ou indiretamente, de infração penal. (Redação dada pela Lei n ${ }^{\circ}$ 12.683, de 2012) [...]

$\S 5^{\circ}$ A pena poderá ser reduzida de um a dois terços e ser cumprida em regime aberto ou semiaberto, facultando-se ao juiz deixar de aplicá-la ou substituí-la, a qualquer tempo, por pena restritiva de direitos, se o autor, coautor ou partícipe colaborar espontaneamente com as autoridades, prestando esclarecimentos que conduzam à apuração das infrações penais, à identificação dos autores, coautores e partícipes, ou à localização dos bens, direitos ou valores objeto do crime. (Redação dada pela Lei ${ }^{\circ}$ 12.683, de 2012)
\end{abstract}

Desde de 09 de julho de 2012, que pode o magistrado aplicar a delação premiada, também na fase executória, consoante a determinação legal.

Podemos falar, seguramente, que a Lei 9613/1998 ampliou o rol de benefícios ao delator, a exemplo do que disciplinavam as leis anteriores e a Lei 12.683/2012 estendeu o lapso de tempo da possibilidade da delação. É uma questão de política criminal.

A natureza jurídica, nesse caso, é mista, vale dizer, é causa de diminuição de pena, de aplicação de regime mais benéfico ou ainda de substituição da pena privativa de liberdade pela restritiva de direitos.

\subsection{LEI 9.807 DE 13 DE JULHO DE 1999 (PROTEÇÃO À VÍTIMA E TESTEMUNHAS).}

Esta lei é um sistema de proteção que visa dar segurança àqueles colabores da luta contra o crime. No tocante à delação premiada, pela interpretação da norma penal, o benefício será dado a qualquer delator que colaborar com informações que podem levar a uma das finalidades trazidas pelo art. 14 da citada lei, por causa das expressões “indiciados” ou “acusados”, deixando claro a amplitude “mens legislatoris”: 
Art. 14. O indiciado ou acusado que colaborar voluntariamente com a investigação policial e o processo criminal na identificação dos demais coautores ou partícipes do crime, na localização da vítima com vida e na recuperação total ou parcial do produto do crime, no caso de condenação, terá pena reduzida de um a dois terços.

Não há o que se discutir no aspecto da natureza jurídica, estando claro pela própria redação dada, que se trata de causa de diminuição de pena, a ser oferecida a todo acusado ou indiciado que colabore para resolver algum dos dois problemas propostos: a localização da vítima com vida; e/ou a recuperação total ou parcial do produto do crime

Um desses pressupostos devem ser preenchidos, obrigatoriamente, afora a confissão, que também pressupõe condição de aplicação da delação premiada.

\subsection{LEI 11.343 DE 23 DE AGOSTO DE 2006.}

Essa Lei disciplina os crimes de tráfico de entorpecentes, abarcando a possibilidade de benefício ao colaborador espontâneo, a fim de embalar a cooptação de pessoas que desejam não ser mais membro de organização criminosa, não importando por quais motivos assim o querem:

Art. 41. O indiciado ou acusado que colaborar voluntariamente com a investigação policial e o processo criminal na identificação dos demais coautores ou partícipes do crime e na recuperação total ou parcial do produto do crime, no caso de condenação, terá pena reduzida de um terço a dois terços.

É interessante notar, embora não seja dispositivo abrangido pela delação premiada, a Lei de drogas só permitirá a redução de pena, entre outros requisitos àqueles que não forem envolvidos com organização criminosa:

Art. 33. Importar, exportar, remeter, preparar, produzir, fabricar, adquirir, vender, expor à venda, oferecer, ter em depósito, transportar, trazer consigo, guardar, prescrever, ministrar, entregar a consumo ou fornecer drogas, ainda que gratuitamente, sem autorização ou em desacordo com determinação legal ou regulamentar: [...]

$\S 4^{\circ}$ Nos delitos definidos no caput e no $\S 1^{\circ}$ deste artigo, as penas poderão ser reduzidas de um sexto a dois terços, desde que o agente seja primário, de bons antecedentes, não se dedique às atividades criminosas nem integre organização criminosa. (Vide Resolução n ${ }^{0}$ 5, de 2012)

\subsection{LEI 12.850 DE 02 DE AGOSTO DE 2013.}


Essa lei trata do combate ao crime organizado, prevendo medidas de repressão mais eficazes, através de uma investigação criminal mais profícua e busca por meios de obtenção de prova.

Certamente, de acordo com o que outrora foi assentado, não foi a primeira lei sobre o tema, mas foi a mais marcante, tendo em vista todo o cenário de discussão jurídica a respeito da concretização de seus comandos.

Tal lei traz a definição de organização criminosa. Vejamos:

\begin{abstract}
Art. $1^{\circ}$ Esta Lei define organização criminosa e dispõe sobre a investigação criminal, os meios de obtenção da prova, infrações penais correlatas e o procedimento criminal a ser aplicado.

$\S 1^{\circ}$ Considera-se organização criminosa a associação de 4 (quatro) ou mais pessoas estruturalmente ordenada e caracterizada pela divisão de tarefas, ainda que informalmente, com objetivo de obter, direta ou indiretamente, vantagem de qualquer natureza, mediante a prática de infrações penais cujas penas máximas sejam superiores a 4 (quatro) anos, ou que sejam de caráter transnacional.
\end{abstract}

De fato essa é a lei que regulamenta a delação premiada, trazendo inclusive sua natureza processual, senão vejamos:

Art. $3^{\circ}$ Em qualquer fase da persecução penal, serão permitidos, sem prejuízo de outros já previstos em lei, os seguintes meios de obtenção da prova:

I - colaboração premiada;

Além dessa novidade, a natureza jurídica da colaboração premiada foi especificada, quanto aos crimes cometidos por organizações criminosas, sendo causa de diminuição de pena, desde que a colaboração seja voluntária e eficaz.

Art. $4^{\circ} \mathrm{O}$ juiz poderá, a requerimento das partes, conceder o perdão judicial, reduzir em até 2/3 (dois terços) a pena privativa de liberdade ou substituí-la por restritiva de direitos daquele que tenha colaborado efetiva e voluntariamente com a investigação e com o processo criminal, desde que dessa colaboração advenha um ou mais dos seguintes resultados

\title{
CONSIDERAÇÕES FINAIS
}

A corrente favorável ao Instituto da Delação Premiada parte do pressuposto de que os benefícios advindos da delação são incalculáveis, disponibilizando o acesso a informações que, por outro método de investigação, não seriam descobertos, possibilitando assim o desmantelamento de Organizações Criminosas, inclusive as da espécie mafiosa. 


\section{Raphael Douglas Vieira \& Juan Pablo Morillas}

Portanto, a delação, é um poderoso instituto no combate às organizações criminosas, pois ainda na fase de investigação criminal o colaborador, além de confessar seus crimes para as autoridades, evita a consumação de outras infrações, bem como auxilia concretamente a polícia e o Ministério Público nas suas atividades de recolher provas contra os demais coautores, possibilitando suas prisões (SILVA, 2005, p. 289).

Em se tratando daquilo que a doutrina denomina “direito premiado", o que ocorre é que por razões pragmáticas o legislador resolveu privilegiar as informações do coautor ou partícipe do crime, que venham a favorecer a sociedade com o seu desvendar e a indicação de seus autores. Se o crime privilegia o Código de Omertá entre seus autores, a ordem jurídica o faz em relação à transparência e apuração dos fatos e da autoria, ainda que esta venha da parte do coautor ou do partícipe. Nesse sentido, o criminoso ao confessar o delito cometido, movido pelo arrependimento estará compreendendo o aspecto negativo do ato praticado, passando a aceitar o castigo a que ele esteja sujeito e fica insatisfeito consigo mesmo pela violação da lei, estando disposto a não mais cometê-los, ou ainda pode o coautor eleger o instituto visando um alivio interior (GUIDI, 2006, p. 156).

Na verdade, a obrigação é para com a sociedade. O que existe realmente é o dever de colaborar para a elucidação do crime, pois esse é o interesse social (LIMA, 2005, p. 89).

A favor do instituto, pode-se invocar as sábias palavras do jurista Ihering: "um dia os juristas tornarão a ocupar-se do direito premiado e o farão quando pressionados pela necessidade prática... não tanto no aspirante ao prêmio, mas ao superior interesse da comunidade” (GUIDI, 2006, p. 162).

Em contraposição, os que criticam o Instituto da Delação Premiada partem do princípio de que tal comportamento (o ato de delatar) atrai repulsa até mesmo entre os criminosos, enfraquecendo a eficácia social da norma jurídica, pois para que seja prontamente considerada, deve estar em conformidade com os valores do povo no qual foi submetido à referida norma e, decididamente, a deslealdade não é um valor da sociedade. (SANTOS, 2007) Eugênio Raúl Zaffaroni pontua:

“[...] A impunidade de agentes encobertos e dos chamados "arrependidos” constitui uma séria lesão à eticidade do Estado, ou seja, ao princípio que forma parte essencial do estado de Direito: o Estado não pode se valer de meios imorais para evitar a impunidade [...] O Estado está se valendo da cooperação de um delinquente comprada a preço de sua impunidade, para "fazer justiça”, o que o Direito liberal repugna desde os tempos de Beccaria. (ZAFFARONI apud GUIDI, 2006, p.143)”

Outro argumento utilizado contra esse instituto é que os acordos de colaboração com a justiça ferem o postulado básico nulla poena sine iudicio, porque aplicam pena sem processo, ofendendo a inderrogabilidade da jurisdição (CARVALHO; COUTINHO, 2006).

Isso porque ao firmar acordo de delação com o acusado, o Ministério Público invade o monopólio legal e jurisdicional da pena repressiva. A justiça negociada viola esse monopólio judicial, pois a violência repressiva da pena não passa mais pelo controle jurisdicional e tampouco submete-se aos limites da legalidade, pois está nas mãos do Ministério Público e 
submetido à sua discricionariedade (LOPES JÚNIOR apud CARVALHO; COUTINHO, 2006).

Argumenta-se também contra a delação premiada que esta fere o princípio da igualdade, ao oferecer benefício da redução de pena apenas aos delinquentes de crimes hediondos e de crime organizado, não tendo oportunidade os criminosos de outros tipos de crimes. Fere também o princípio da proporcionalidade da pena, uma vez que se punirá com penas diferentes pessoas envolvidas no mesmo fato e com idênticos graus de culpabilidade (GUIDI, 2006).

A delação premiada é a prova da ineficiência do Estado atual para investigar e punir os crimes e os criminosos. É a falência estatal. Por falta de preparo técnico e de estrutura tecnológica, o Estado se vê obrigado a transigir com os mais elementares princípios éticos (CERVINI; GOMES, 1997).

Apesar disso, ao nosso ver, trata-se de um Instituto que já possibilitou o desmantelamento das maiores organizações criminosas do planeta, tais como a "Cosa Nostra" e a "Camorra”, na Itália, o "ETA”, na Espanha, o "IRA”, na Irlanda, e, no Brasil, vem desmascarando a rede de corrupção que permeia todo o cenário político nacional há décadas. Por isso, deve ser prestigiado, não só por sua eficácia jurídica, como também por sua eficácia social, posto que o Direito deve, antes de tudo, proporcionar o bem comum e o desenvolvimento social.

\section{REFERÊNCIAS BIBLIOGRÁFICAS}

BRASIL. Lei 12.694 de 24 de julho de 2012 (processo e o julgamento colegiado em primeiro grau de jurisdição de crimes praticados por organizações criminosas). Disponível em: <http://www.planalto.gov.br/ccivil_03/_ato2011-2014/2012/lei/l12694. htm>. Acesso em: 31 de março de 2018.

. Lei 9.080 de 19 de julho de 1995. Disponível em <http://www.planalto.gov.br/ ccivil_03/leis/L9080.htm>. Acesso em 31 de março de 2018.

. Lei n ${ }^{\circ} 9.807$, de 13 de julho de 1999. Estabelece normas para a organização e a manutenção de programas especiais de proteção a vítimas e a testemunhas ameaçadas, institui o Programa Federal de Assistência a Vítimas e a Testemunhas Ameaçadas e dispõe sobre a proteção de acusados ou condenados que tenham voluntariamente prestado efetiva colaboração à investigação policial e ao processo criminal. Disponível em: http://www.planalto.gov.br/ccivil_03/leis/L9807.htm. Acesso em: 31 de março de 2018. 
Lei ${ }^{\circ}$ 11.690, de 09 de junho de 2008. Altera dispositivos do Decreto-Lei $n^{\circ} 3.689$, de 3 de outubro de 1941 - Código de Processo Penal, relativos à prova, e dá outras providências. Brasília, 2008. Disponível em: Acesso em: 31 de março de 2018.

BITTAR, Walter Barbosa. Delação Premiada: direito estrangeiro, doutrina e jurisprudência. Rio de Janeiro: Lumen Juris, 2011.

BRITO, Michelle Barbosa de. Delação Premiada e decisão penal: da eficiência à integridade. Belo Horizonte: D’Plácido, 2016

CARVALHO, Edward Rocha de; COUTINHO, Jacinto Nelson de Miranda. Acordos de delação premiada e o conteúdo ético mínimo do Estado. Revista de Estudos Criminais, Porto Alegre: Fonte do Direito, ano VI, n. 22, 75-84, abr./jun. 2006

CARVALHO, Natália Oliveira de. A delação premiada no Brasil. Rio de Janeiro: Lumen Juris, 2009.

CAMARGO, Beatriz Corrêa. Delação premiada: moral, legitimidade, arranjo constitucional. Boletim IBCCRIM, São Paulo, v. 20, n. 232, p. 7-8, mar. 2012.

CERQUEIRA, Thales Tácito Pontes Luz de. Delação premiada. Revista Jurídica Consulex, Brasília, v. 9, n. 208, p. 24-33, set. 2005.

CERVINI, Raul. GOMES, Luiz Flavio. Crime organizado: enfoque criminológico, jurídico (lei 9034/95) e político criminal. $2^{\text {a }}$ Ed., São Paulo: Revista dos Tribunais, 1997

DOTTI, René Ariel. Casos criminais célebres. São Paulo: Revista dos Tribunais, 2003, p. 27 apud FERREIRA, Regina Cirino Alves. Caso Tiradentes e repressão penal: passado e presente. Revista das [20??]. Liberdades. Disponível em <http://www.revistaliberdades.org.br/site/outrasEdicoes/outrasEdicoesExibir.php?rcon_id=11 \# ftn30>. Acesso em 31 de março de 2018

FERREIRA, A. B. H. Aurélio: Dicionário da língua portuguesa. 7. ed. Rio de Janeiro: Positivo, 2008. Curitiba: 2008

GARCIA, Roberto Soares. Delação Premiada: ética e moral às favas! Boletim IBCCRIM, São Paulo, ano 13, nº 159, fev. 2006.

GONZÁLEZ, Ana Lúcia Stumpf. A delação premiada na legislação brasileira. Rio Grande do Sul - RS, 2010, p.10. Disponível em <http://www.lume.ufrgs.br/handle/10183/27024>. Acesso em 31 de março de 2018

GUIDI, José Alexandre Marson. Delação Premiada no Combate ao Crime Organizado. São Paulo: Lemos de Oliveira, 2006.

LIMA, Carlos Fernando dos Santos. Delação para colaborar com a sociedade. Revista Jurídica Consulex, Brasília, ano IX, n. 208, p. 31, 15 set. 2005.

LOPES JÚNIOR, Aury. Direito processual penal. 9. ed. São Paulo: Saraiva, 2012. 
MAIEROVITCH, Wálter. Delação premiada. Carta Capital: 2014. Disponível em $<$ http://www.cartacapital.com.br/revista/819/delacao-premiada-4253.html>. Acesso em 31 de março de 2018

MOSSIM, Antônio Heráclito e MOSSIM, Júlio César O.G. Delação premiada: aspectos jurídicos. São Paulo: J.H. Mizuno, 2016

MORO, Sérgio Fernando Moro. Considerações sobre a Operação Mani Polite. Revista Conselho Estadual de Justiça, Brasília, n. 26, jul./set. 2004, p. 56-62. Disponível em $<$ http://jornalggn.com.br/sites/default/files/documentos/art201 50102-03.pdf>. Acesso em 31 de março de 2018.

NUCCI, Guilherme de Souza. Manual de processo penal e execução penal. $4^{\mathrm{a}}$ Ed. São Paulo: Revista dos Tribunais, 2008.

OLIVEIRA, Eugênio Pacelli de. Curso de processo penal. $13^{\mathrm{a}}$ Ed. Rio de Janeiro Lumen Juris, 2015.

PIERAGELI, José Henrique. Códigos Penais do Brasil: Evolução histórica. 2. ed. São Paulo: Revistas dos Tribunais,2011, p. 100 apud MOSSIM, Antônio Heráclito e MOSSIM, Júlio César O.G. Delação premiada: aspectos jurídicos. São Paulo: J.H. Mizuno, 2016.

SANTOS, Heider Silva. A delação premiada e sua (in) compatibilidade com o ordenamento jurídico pátrio. Jus Navigandi, Teresina, ano 11, n. 1495.

SILVA, Eduardo Araújo da. Crime Organizado: Procedimento probatório. São Paulo: Atlas, 2003.SOUZA, Marcus Valério Saavedra Guimarães de. A lei de proteção às testemunhas Disponível em: http://www.valeriosaavedra.com/conteudo_4_a-lei-de-protecao-stestemunhas.html. Obra intelectual protegida pela Lei 9.610/98. Consultada em 31 de março de 2018.

TÁVORA, Nestor e ALENCAR, Rosmar Rodrigues. Curso de Direito Processual Penal. 9.ed., $3^{\mathrm{a}}$ Tiragem, Revista atualizada e ampliada. Salvador: Juspodium, 2014.

TUCCI, Rogério Lauria. Direitos e garantias individuais no processo penal brasileiro. $3^{\mathrm{a}}$ Ed. São Paulo: Revista dos Tribunais, 2009. 